\title{
Effect of Moringa oleifera (Moringa) Supplementation via Urea Molasses Multi-nutrient Moringa Block(UM3B) on Nutrient Intake and Utilization in Bali Cattle
}

\author{
Abd Malik*, Aam Gunawan, Siti Erlina, Neni Widaningsih, Rizkie E
}

Department of Animal Science, Faculty of Agriculture, Islamic University of Kalimantan, Muhammad Arsyad Al Banjari. Banjarmasin. South Kalimantan. Indonesia.

\begin{abstract}
The objective of the study was to determine the effect of Moringa oleifera supplementation via Urea Molasses Multi-nutrient moringa Block (UM3B) on consumption and digestibility of dry matter and organic matter in the Bali cattle. A total of 16 Bali cattle aged 2-4 years, of same sex ratio, body weight around $200-250 \mathrm{~kg}$ was used in this study. The cows were allotted to four equal groups that were placed in individual cages rendered to the distribution of treatment groups. The feed was given in the form of field grass and concentrate. The treatment in the first group (P0) was given UMMB (Urea Molasses Multi-nutrient Block) without moringa, while the second (P1), third (P2) and fourth (P3) groups were given UM3B with 5,10 and 15\% of moringa respectively. The consumption of dry matter and organic matter in the Bali cattle was not significantly different $(\mathrm{P}>0.05)$ between control $(\mathrm{P} 0)$ and all treatment groups. Whereas, the percentage of digestibility of organic matter, as well as, percentage of digestibility of dry matter were significantly different $(\mathrm{P}<0.05)$ between control $(\mathrm{P} 0)$ and treatments of $\mathrm{P} 2$ or $\mathrm{P}$ 3. It is concluded that the consumption, as well as the digestibility of dry matter and organic matter were improved by supplementation of moringa and the best results were obtained at $15 \%$ inclusion of moringa in UM3B.
\end{abstract}

Keywords | Moringa, UM3B, consumption, Nutrient digestibility, Bali cattle

Editor | Asghar Ali Kamboh, Sindh Agriculture University, Tandojam, Pakistan.

Received | January 25, 2019; Accepted | April 28, 2019; Published | June 08, 2019

*Correspondence | Abd Malik, Department of Animal Science, Faculty of Agriculture, Islamic University of Kalimantan, Muhammad Arsyad Al Banjari. Banjarmasin. South Kalimantan. Indonesia; Email: sidol_99@yahoo.com

Citation | Malik A, Gunawan A, Erlina S, Widaningsih, Rizkie E (2019). Effect of moringa oleifera (moringa) supplementation via urea molasses multi-nutrient moringa block (um3b) on nutrient intake and utilization in bali cattle. J. Anim. Health Prod. 7(2): 70-74.

DOI | http://dx.doi.org/10.17582/journal.jahp/2019/7.2.70.74

ISSN | 2308-2801

Copyright (C) Malik 2019 et al. This is an open access article distributed under the Creative Commons Attribution License, which permits unrestricted use, distribution, and reproduction in any medium, provided the original work is properly cited.

\section{INTRODUCTION}

$\mathrm{O}^{\prime}$ ne of the significant factors that must be considered in the cattle industry in tropical countries is the decline in production and forage quality in the dry season. This needs to be anticipated because it will affect the production and reproduction of the cattle. Mangistu and Hassen (2018) revealed that cattle in tropical countries like Bali cattle in Indonesia is largely dependent on fibrous feeds mostly crop residues and low value pasture that are poor in crude protein, minerals, and vitamins. Supplementation of poor quality feed or deficient of qualities is familiar as a suitable approach to improve their utilization as a feed of animal. Digestibility is an essential factor for assessing the quality of nutrients from a feed ingredient. Ingredients of feed with high digestible constituents are generally high in nutrient value (Lubis, 1992). The value of digestibility coefficient varies depending on the content of each nutrient or type of animal, and some factors like chemical composition, feed processing, amount of nutrition provided, and type of livestock (Astuti et al., 2009).

Moringa oleifera was called moringa is one of the legume that have the potential to substitute nutrient deficiencies, because of its complete nutritional contentas animal feed (Baptista et al., 2017; Agboun et al., 2016; Ahmad et al., 2016; Gupta et al., 2012). While, Fungli (2001) reported that the leaves of moringa contain $27.1 \%$ protein, 2050 
$\mathrm{kcal} / \mathrm{kg}$ metabolized energy, respectively. Furthermore, Witt (2016) and Gopalakrishnan et al. (2016) revealed that leaves of moringa also had diverse vitamins, minerals, and containing all essential amino acids. Many researchers reported that moringa can be used as an animal feed. The addition of moringa leaves meal to goats feed increased milk production (Kholif et al., 2015) upsurge feed intake and performance of chickens (Sultana et al., 2014) and improve average gain in rabbit (Safwat et al., 2014).

The use of moringa leaves flour as an ingredients in the preparation of a urea-molasses block is a good breakthrough in order to overcome nutritional deficiencies in cattle during the dry season (De and Singh, 2003). Since the feed is composed of various ingredients such as urea and molasses. Molasses and urea are recognized to respectively cover accessible energy and nitrogen and are used to increase feed quality (Preston and Leng, 1990). Additional feed like of urea molasses mineral block (UMMB) has been widely studied as a useful strategy in providing essential nutrients to optimize rumen fermentation of poor quality feeds in animals (Habib et al., 1991). Furthermore, UMMB also has been used in large and small ruminants as supplementation to improve feed consumption and digestibility particularly in developing countries (De and Singh, 2003; Vu et al.,1999; Verma et al., 1998; Srinavasan and Gupta 1997).

Thus, the hypothesis can be compiled as the addition of moringa leaf flour in urea molasses multi-nutrient moringa block (UM3B) can increase nutrient digestibility in cattle. The objective of the present study was to evaluate the effect of moringa supplementation via UM3B on consumption and digestibility of dry matter and organic matter on the Bali cattle.

\section{MATERIALS AND METHODS}

\section{Formulation OF UMMB AND UMMMB (UM3B)}

Urea molasses multi-nutrient block (UMMB) was prepared by a cold mixing process and the mixture was poured into the specially intended mold to form blocks considering $1 \mathrm{~kg}$ each. Mold was made with metal pieces, which gives cylindrical shape with a hole at the center, which enables to tie blocks, somewhere in stall/shed. The physical composition of UMMB is given in Table 1.

\section{Animals and Feeding Management}

A total of sixteen Bali cattle weighing around $200-250 \mathrm{~kg}$ aged 2-4 years and the same sex ratio (male or female) were used for the present study. The cattle were placed in individual stalls. The animals were allotted to four treatment groups; each group was consisting of four cattle. Group $1(\mathrm{P} 0=\mathrm{UMMB}$ without moringa $)$, group $2(\mathrm{P} 1=\mathrm{UMMB}$ with $5 \%$ of moringa), group $3(\mathrm{P} 2=\mathrm{UMMB}$ with $10 \%$ of moringa) and group 4(P3=UMMB with $15 \%$ of moringa). The UMMB (P0) and UM3B (P1, P2, P3) were given $300 \mathrm{~g} / \mathrm{cow} /$ day. The feeding standard during the research was calculated by the National Research Council (NRC). All cattle were raised under similar grazing system on the various kinds of local grasses such asilalang (Imperata cylindrica) and carex (Carexstricta) and supplemented with rice bran which was given as much as $1.5 \mathrm{~kg} / \mathrm{head} /$ day. The animals were made free from internal parasites by using anthelmintic albendazole at the rate of $0.5 \mathrm{mg} / \mathrm{kg}$ body weight.

Table 1: Formulations used for preparing of urea molasses multi-nutrient block (UMMB) and urea molasses multinutrient moringa block (UM3B).

\begin{tabular}{lllll}
$\begin{array}{l}\text { Ingredients } \\
\text { (on a percent- } \\
\text { age basis) }\end{array}$ & $\begin{array}{l}\text { Formulation (\%) } \\
\text { P0 }\end{array}$ & $\begin{array}{l}\text { P1 } \\
\text { (UMMB) } \\
\text { (UM3B) }\end{array}$ & $\begin{array}{l}\text { P2 } \\
\text { (UM3B) }\end{array}$ & $\begin{array}{l}\text { P3 } \\
\text { (UM3B) }\end{array}$ \\
Moringa & - & 5 & 10 & 15 \\
Sago palm & - & 1 & 2 & 3 \\
\hline Mineral & 5 & 5 & 5 & 5 \\
\hline Urea & 5 & 5 & 5 & 5 \\
\hline Salt & 5 & 5 & 5 & 5 \\
\hline Chalk & 7 & 7 & 7 & 7 \\
\hline Maize & 5.1 & 12.2 & 9.7 & 8.9 \\
\hline Soy & 15 & 12.2 & 9.5 & 6.3 \\
Rice bran & 22.9 & 17.6 & 11.8 & 9.8 \\
\hline Molasses & 35 & 35 & 35 & 35 \\
Total & 100 & 100 & 100 & 100
\end{tabular}

The trial was conducted for 21 days after 14 days of adaptation period, and last 7 days were used for collection of samples. The data was collected as a measurement of feed consumption by weighing feed given and remaining feed for 24 hours. Then the feed samples and the remaining feed were taken by $10 \%$. The fecal collections are carried out by weighing stool produced for 24 hours by each individual cow. The resulting stool is taken $10 \%$ to be dried and then mashed and mixed until homogeneous. Consumption (feed intake) was assessed by (\%DM feed intake $\mathrm{x}$ total consumption) - (\% DM remaining $\mathrm{x}$ total remaining). Whereas, nutrients digestibility was assessed with (nutrients content of feed- nutrients content of feces / nutrients content of feed x $100 \%$ ), respectively. Furthermore, the material is analyzed to determine the content of dry matter and organic matter.

The chemical composition of forage, urea molasses multi-nutrient moringa block (UM3B), and feces were analyzed using methods recommended by AOAC (1994), while acid detergent fiber (ADF) and neutral detergent fiber 
(NDF) were calculated according to methods of Van Soest et al. (1991).

\section{Statistical Analysis}

The data of block consumption was analyzed statistically using analysis of variance (ANOVA). The significant differences between means were compared using Duncan's multiple range tests. The difference was considered as significant when $\mathrm{p}<0.05$.

\section{RESULTS AND DISCUSSION}

The results of the averages of dry matter and organic matter consumption after inclusion of various doses of moringa in UM3B were shown in Figure 1. The consumption of dry matter and organic matter in the Bali cattle was not significantly different $(\mathrm{P}>0.05)$ between control $(\mathrm{P} 0)$ and all treatments, however, the data showed an increasing trend via the addition of moringa doses in treatments $\mathrm{P} 1, \mathrm{P} 2$ and $\mathrm{P} 3$. The results wereattained in agreement with the findings of the previous study by Sjofjan (2008) who revealed that administration of moringa leaves in feed can increase feed consumption and weight gain. Furthermore, Raman et al. (2018) revealed that leaf of moringa as a protein source in diet increased feed intake in cattle.



Figure 1: The average consumption of dry matter and organic matter by supplementation of various doses of moringa (UM3B) in Bali cattle.

On the other hand, the percentage of digestibility of dry matter was significantly different $(\mathrm{P}<0.05)$ between control (P0) and treatments of $\mathrm{P} 2$ or $\mathrm{P} 3$; however, the digestibility of dry matter in the treatment of $\mathrm{P} 3$ was significantly higher $(\mathrm{P}<0.05)$ than that of $\mathrm{P} 2$ (Table 2). Likewise, the percentage of digestibility of organic matter was significantly different $(\mathrm{P}<0.05)$ between control $(\mathrm{P} 0)$ and treatments of $\mathrm{P} 2$ or $\mathrm{P} 3$, where the digestibility of organic matter in the treatment of $\mathrm{P} 3$ was significantly higher $(\mathrm{P}<0.05)$ than that of $\mathrm{P} 2$.

Increased digestibility of dry matter and organic matter in treatments $\mathrm{P} 1, \mathrm{P} 2$ and $\mathrm{P} 3$ were turned out to be in line with the addition of moringa doses in UM3B. This is probably because moringa supplements contain complete nutrients that probably have impact on the microbial population of rumen, as it is well established that increased microbial population in rumen may significantly improve the protein consumption. The results were strengthened by Yami (2007) who stated that supplementation with Urea Molasses Multi-Nutrient Blocks (UMMB) can increase digestibility of fibrous feeds and feed intake. On the other hand, Mubi et al. (2011) as well as Mahesh and Mohini (2014) reported that feed technology like UMMB could be used to improve the efficiency of nutrition.

Table 2: The average digestibility of nutrients by supplementation of various doses of moringa (UM3B) in Bali cattle.

\begin{tabular}{lllll} 
& \multicolumn{5}{c}{ Moringa dose in the formula of UM3B } \\
Parameters & P0(0\%) & P1 (5\%) & P2 (10\%) & P3 (15\%) \\
Digestibility of & 68.09 & 73.71 & 79.06 & 86.07 \\
dry matter & $\pm 0.91^{\mathrm{a}}$ & $\pm 0.79^{\mathrm{ab}}$ & $\pm 1.02^{\mathrm{b}}$ & $\pm 0.70^{\mathrm{c}}$ \\
Digestibility of & 22.58 & 23.05 & 33.06 & 60.58 \\
organic matter & $\pm 0.87^{\mathrm{a}}$ & $\pm 0.59^{\mathrm{ab}}$ & $\pm 0.79^{\mathrm{b}}$ & $\pm 0.51^{\mathrm{c}}$ \\
Crude fiber & 35.73 & 40.19 & 36.33 & 37.97 \\
& \pm 0.51 & \pm 0.94 & \pm 0.85 & \pm 0.61
\end{tabular}

a,b,c Values in the same row with different superscripts indicate significant difference at $\mathrm{P}<0.05$,

Digestibility of dry matter and organic matter in $15 \%$ UM3B in Bali cattle showed better effects. This proves that the quantity and quality of moringa were able to provide nutrients for the rumen microbes so that it can raise the nutrient digestibility. This is in accordance with the opinion of previous workers those reported that several factors can influence ration digestibility including physical form, feed flow rate through the gastrointestinal tract, the ratio of food substances in the rumen and the complete nutritional composition of nutrition (MCdonald et al., 1995; Abel et al., 2014; Saidu et al., 2017).

\section{CONCLUSION}

It can be concluded that the feed intake, as well as digestibility of dry matter and organic matter were improved by all levels of moringa inclusion; however, the best results were obtained by inclusion of $15 \%$ moringa level in UM3B.

\section{ACKNOWLEDGMENTS}

The funding of this project by Direktorat Risetdan Pengabdian Masyarakat (DRPM) of the Ministry of Research, Technology, Higher Education, Republic of Indonesia. The authors also were grateful to Mr. Basuki and Mrs Arini for their assistance. 


\section{CONFLICT OF INTEREST}

All the authors declare that they have no conflict of interest.

\section{AUTHORS CONTRIBUTION}

The study (experimental) design was achieved by AbdMalik, the actual research organized by Aam Gunawan and Neni W while Siti Erlina and Rizkie tabularized the data and done the statistical analyses.

\section{REFERENCES}

-Abel FA Silas, Adeyemi Olajide A, Eruvbetine Daisy, Sogunle O Mark, Oluwole Oluwatoyin B, Elemo Gloria N (2014). Effect of stocking density and quantitative feed restriction on growth performance, digestibility, haematological characteristics and cost of starting broiler chicks. J. Anim. Health Prod. 2 (4): 60 - 64. https://doi.org/10.14737/ journal.jahp/2014/2.4.60.64

-Agboun TDT, Apugo-Nwosu TU, Mohammed JA, Ameh AO, Abubakar G, Mustapha M, Okoro P (2016). Potential of using Moringa oleifera seeds, in the bioremediation of soil contaminated by crude oil. Br. J. Appl. Sci. Technol. 15: 1-8 https://doi.org/10.9734/BJAST/2016/9358.

-Ahmad W, Noor MA, Afzal I, Bakhtavar MA, Nawaz MM, Sun X, Zhao M (2016). Improvement of sorghum crop through exogenous application of natural growth promoting substances under a changing climate. J. Sustainab. 8: 1330. https://doi.org/10.3390/su8121330

-AOAC (1994). Official Methods of Analysis (16th Ed.) Association of Official Analytical Chemists, 14 th ed. Arlington, VA.

-Astuti A, Ali Agus, Subur PS (2009). The effect of high quality feed supplement addition on the nutrient consumption and digestibility of early lactating dairy cow Buletin Peternakan. 33(2): 81-87. https://doi.org/10.21059/buletinpeternak. v33i2.120

- Baptista ATA, MO Silva, RG Gomes, Bergamasco R, Vieira MF, Vieira AMS (2017). The protein fractionation of seeds of Moringaoleifera lam, and its application in superficial water treatment. Sep. Purif. Technol. 180: 114-124. https:// doi.org/10.1016/j.seppur.2017.02.040

-De D, Singh GP (2003). Effect of Cold Process Monensin Enriched UMMB on Performance of Crossbred Calves Fed a Wheat Straw Based Diet. Anim. Feed Sci. Technol. 103: 51-61. https://doi.org/10.1016/S0377-8401(02)00256-0

- Fuglie L (2001). The Miracle Tree. (The Multiple Attributes of Moringa). CWS. Dakar, Sinegal. Feed. Elsevier. Amsterdam. Pp. 373-409.

-Gopalakrishnan L, Doriya K, Kumar DS (2016). Moringa oleifera: A review on the nutritive importance and its medicinal application. Food Sci. Human Wellness. 5: 49-56 https://doi.org/10.1016/j.fshw.2016.04.001.

- Gupta R, M Mathur, VK Bajaj, P Katariya, Yadav S, Kamal R, Gupta RS (2012). Evaluation of antidiabetic and antioxidant activity of Moringa oleifera in experimental diabetes. J. Diabet. 4: 164-171. https://doi.org/10.1111/j.17530407.2011.00173.x
- Habib G, SBA Shah, Waheedullah G, Jabbar, Ghufranullah (1991). The importance of urea molasses block and bypass protein on animal production. In; Proc. Intern. Symp Nuclear and related Tech. Anim. Prod. Helath. Vienna Austria. Pp:133-144.

-Kholif AE, Gouda GA, Morsy TA, Salem AZM, Lopez S, Kholif AM (2015). Moringa oleifera leaf meal as a protein source in lactating goat diet: intake of feed, digestibility, ruminal fermentation, milk yield and compositions, and its fatty acids profile. Small Rumin. Res. 129: 129-137. https:// doi.org/10.1016/j.smallrumres.2015.05.007

-Lubis DA (1992). Ilmu Makanan Ternak. Cetakan Ulang. PT Pembangunan, Jakarta.

-Mahesh MS, Mohini M (2014). Crop Residues for Sustainable Livestock Production. Adv. Dairy Res. 23: 1-2.

- Mengistu G,W Hassen (2018). Supplementary Feeding of Urea Molasses Multi-Nutrient Blocks to Ruminant Animals for Improving Productivity. Acad. Res. J. Agri. Sci. Res. 6(2): 52-61.

- McDonald P, RA Edwards, JFD Greenhalaghand, CA Morgan (1995). Anim. Nutr. Fifth Ed. John Willey and Sons, Inc, New York.

-Mubi AA, Kibon A, Mohammed ID (2011). Effects of multinutrient blocks supplementation on the performances of grazing Sheep of Yankasain the wet season of guinea Savanna Region of Nigeria. Int. J. Sustain. Agric. 3(3): 103-106.

-Preston TR, Leng R (1990). Matching ruminant production systems with available resources in the Tropics and Subtropics. CTA, Netherlands.

-Raman JK, Catarina M. Alves, Edgard G (2018). A review on moringa tree and vetiver grass- Potential biorefinery feedstocks. Bioresource Technol. 249:1044-1051.

-Safwat AM, Sarmiento-Franco L, Santos-Ricalde R, Nieves D (2014). Effect of dietary inclusion of Leucaena leucocephala or Moringa oleifera leaf meal on performance of growing rabbits. Trop. Anim. Health Prod. 46: 1193-1198. https:// doi.org/10.1007/s11250-014-0626-1

-Saidu AM, Abbah JI, Kolo UM, Laku D, Adam MK (2017). Effects of Aspirating Long Needle Rumenocentesis on Haematology and Some Physiological Parameters of Yankasa Sheep in Maiduguri. J. Anim. Health Prod. 5(2): 58-63.

-Sjofjan O (2008). Efekpengguna antepung daunkelor (Moringaoeifera) dalampakanter hadappen ampilan produksiayam pedaging. Seminar Nasional Teknologi Peternakandan Veteriner, Bogor.Indonesia.

-Srinivas B, Gupta BN (1997). Rumen Fermentation, Bacterial and Total Volatile Fatty Acid (TVFA) Production Rates in Cattle Fed on Urea-Molasses-Mineral Blocks Licks Supplement. Anim. Feed Sci. Technol. 65: 275-286. https:// doi.org/10.1016/S0377-8401(96)01062-0

-Sultana N, Alimon AR, Haque KS, Sazili AQ Yaakub H, Hossain SMJ (2014). The effect of cutting interval on yield and nutrient composition of different plant fractions of Moringa oleifera tree. J. Food Agric. Environ. 12: 599-604.

-Van soest PJ, Robertson JB, Lewis BA (1991). Methods for dietary fibre, neutral detergent fibre and non-starch polysaccharides in relation to animal nutrition. J. Dairy Sci. 74: 3583-3597. https://doi.org/10.3168/jds.S00220302(91)78551-2

-Verma AK, Mehra UR, and Dass RS (1998). Nutrient Utilization by Murrah Buffaloes (Bubalus bubalis) as Influenced by Varying Levels of UMMB on Wheat Straw 
Based Diets. Anim. Feed Sci. Technol. 73: 339-346. https:// doi.org/10.1016/S0377-8401(98)00142-4

-Vu DD, Cuong LX, Dung CA, Hai PH (1999). Use of UreaMolasses-Multinutrient Block and Urea-Treated Rice Straw for Improving Dairy Cattle Productivity in Vietnam. Prev. Vet. Med. 38: 187-193. https://doi.org/10.1016/S01675877(98)00124-X
-Witt KA (2016). The Nutrient Content of Moringa oleifera Leaves. ECHO Research Note no.1: 1-6. http:// moringatrees.org/. Access Nov. 2017.

-Yami A (2007). How to make Urea Molasses Blocks (UMB) and feed to Sheep and Goats. Technical Bulletin1. Ethiopia Sheep and Goat productivity Improvement Program. R.C. Merkel (ed.). 10Pp. 